\title{
International Journal of Physical Modelling in Geotechnics: Referees 2016
}

The following is a list of referees who have reviewed papers for International Journal of Physical Modelling in Geotechnics between 1 December 2015 and 30 November 2016. The Institution of Civil Engineers is very grateful for their assistance.

We are continually looking for suitable reviewers for papers submitted to International Journal of Physical Modelling in Geotechnics. Papers published in ICE journals must be submitted to at least two independent referees to judge accuracy, style, impact, importance and interest.

O. Adamidis
D. Airey
N. Al Ansari
H. Aldaikh
A. Al-Defae
C. Anagnostopoulos
Z. Arbanas
J. H. Atkinson
M. Awad-Allah
G. Baudouin
C. Beckett
C. Beckett
R. Beddoe
L. Begaj
A. Bezuijen
V. Bhamidipati
S. Bhattacharya
B. Bienen
E. Bilotta
J. Black
M. Blanc
A. Bouafia
E. Bowman
A. Brennan

O. Adamidis

D. Airey

H. Aldaikh

Z. Arbanas

G. Baudouin

C. Beckett

L. Begaj

A. Bezuijen

B. Bienen

E. Bilotta

A. Brenn

A. Bretschneider
B. Byrne
B. Caicedo
J. Cripps
S. Dash
L. Deng
J. Dijkstra
M. Ehrlich
W. El-Sekelly
C. Gaudin
R. Girout
R. Goodey
S. Gourvenec
W. Guo
M. Hakhamaneshi
O. Hamza
O. Hededal
C. Heron
J. K. Holmen
K. Horikoshi
P. Hudacsek
M. Iskander
K. Itoh
A. Ivanovic

If you are interested in reviewing articles on any topic related to physical modelling in geotechnics, please submit your name, qualifications or CV, and areas of expertise. We are in need of individuals who will agree to review papers in a timely fashion (within 3 to 4 weeks of receipt) and provide confidential feedback to the Editorial Advisory Panel concerning the quality of the paper and any suggested revisions that would be appropriate.

If you are such a person, please contact Claire Robinson (tel.: +44 (0)207 665 2241; e-mail: claire.robinson@icepublishing.uk) for more information on the referee process.

J. Izawa
S. W. Jacobsz
O. Jenck
N. J. Jiang
X. Kang
M. Kitazume
R. T. Klinkvort
J. Knappett
P. Kokkali
S. S. Y. Lam
D. Lesniewska
J. Lim
X. Mao
A. Marshall
F. Molenkamp
T. Mukunoki
G. Mullins
K. S. Ng
Q. Ni
S. Nishimura
M. Okamura
U. S. Okyay
M. Omidvar
P. Paniagua

S. Perera

F. S. Tehrani

F. Saboya

J. Seidel

B. Sheil

P. Shepley

C. Smith

M. Stringer

G. Swift

M. Talesnick

R. N. Taylor

A. Tessari

Y. Tian

A. Tomor

J. Toromanovic

M. Valipour

S. Van Baars

S. Vanapalli

R. Wallerand

L. Wang

D. White

D. Wilson

X. Zhao 